\title{
Autologous Dendritic Cell-Adenovirus P53 Vaccine
}

National Cancer Institute

\section{Source}

National Cancer Institute. Autologous Dendritic Cell-Adenovirus P53 Vaccine. NCI

Thesaurus. Code C26445.

An autologous vaccine composed of dendritic cells (DC) that have been transduced with a p53 tumor suppressor gene-modified virus. When the autologous dendritic celladenovirus p53 vaccine is administered, the host cytotoxic T lymphocytes (CTL) are directed against p53-positive tumor cells, which may result in tumor cell death and decreased tumor growth. ( $\mathrm{NCl04)}$ 